\title{
Implementation of Presidential Decree Number 87 of 2016 About Illegal Levies Sweeper Task Force Units Province of East Java
}

\author{
Helmy Perdana Putera Achluddin Ibnu Rochim \\ FISIP, Universitas 17 Agustus 1945, Surabaya, Jl. Semolowaru No. 45 Surabaya, Jawa Timur, Indonesia
}

\begin{abstract}
How is the Presidential Decree Number 87 of 2016 concerning the Illegal Levies Sweeper Task Force be implemented? How is the Policy Model of the Illegal Levies Sweeper Task Force? The analysis highlight of this study is the good governance actors consisting of, first, the state, which is refer to the executive, legislative and judiciary as well as the military. Second, civil society, consisting of NGOs, mass organizations, mass media, associations based on professionalism, religious groups and others. And third, the economic market. All of three good governance actors interact and influence each other in line with their respective capacities.

Analyzed from the Policy of Presidential Decree No. 87 of 2016 as to the Illegal Levies Sweeper Task Force Unit, Policy of the Governor Regulation of East Java No. 188/624/ kpts / 013/2016 regarding to the Establishment of the Illegal Levies Sweeper Task Force (SABER PUNGLI) in East Java and Target Guideline Factors, Communication, Resources, Disposition, Bureaucratic Structure, Implementer Institution Character, Social Condition, Economy, and Politics. Research findings show that subsequently of the implementation of the Provincial / District / City Illegal Levies Task Force Unit activities up to September 12, 2018, there were 712 cases, for law enforcement in the form of catching operations from alleged cases there were 228 suspects, and from UPP both provinces, districts, and the City as many as 133 people got caught handed operation, and accumulate evidence in the form of cash from the hand-catch operation amounted to Rp. 4.862.896.300.

The end result through the socialization / prevention of the illegal levies unit task force eradication activities in the Province, District, and City in 2018 around 534 cases, for law enforcement in the form of catching hand operations at the Provincial, District and City UPPs as many as 31 Hand Catch Operations with the suspect as many as 39 people and the evidence in the form of cash from the Hand Catch Operation total Rp. $402,280,800$, -
\end{abstract}

Keywords : Implementation, Policy, Illegal Levies Sweeper Task Force, Inspectorate Province of East Java

DOI: $10.7176 / \mathrm{PPAR} / 9-4-08$

Publication date: April $30^{\text {th }} 2019$

\section{INTRODUCTION}

Indonesia's development is a change process that going on under a planned, integrated and sustainable manner with the main target being to improve the welfare of human life or community of a nation. Development continuously moves from an unfavorable state of life to a better life in order to achieve a nation's national goals.

In order to achieve its objectives, the Government has bring together programs, targets and activities as guidelines in dealing with 3 (three) main problems of the nation, namely (1) the decline of state authority, (2) the weakening of the national economy, and (3) widespread intolerance and nation's personality crisis.

In the human development sector, efforts to accelerate are dedicated to improving quality of education, health and competitiveness of human resources (HR), to meet the dynamic labor market. While through economic deregulation, thousands of local regulations hinder the business sector have been cut and licensing simplified. In an effort to boost the economic growth pace, the Government has issued 13 (thirteen) policies known as the government's economic policy package. It is realized that economic development acceleration carried out would not succeed well without being supported by political stability and security and legal certainty. Therefore, the legal reform program became the government's strategic agenda at a later stage, to restore public confidence and create justice and legal certainty. This does not mean that this has not been implemented, so far it has indeed been implemented but has not been optimal. Legal reform covers 3 (three) main pillars, namely: 1. Ordering regulations to produce quality regulations; 2. Improvement of institutions / law enforcement officers to create professionalism in law enforcement; and 3. Building a legal culture to create a strong legal culture. In reform stage I in the field of law, there are 5 (five) programs that become priorities, namely: 1 . Eradicating the practice of illegal levies in public service centers, because the practice of extortion causes the bureaucracy to be convoluted and inefficient; 2. Eradication of smuggling, 3. Acceleration of SIM (driver's license), STNK (vehicle's tax), BPKB (Book of Vehicle Holder) and SKCK (Letter of good conduct) services; 3. Relocation and separation of residents of correctional institutions from drugs, terrorism and radicalism; 4. Improvement of patent rights, brand and corruption-free design services with transparent information technology.

In terms of public service basically is the provision of excellent service to the community as realization of the government officials obligations as public servants. But the conditions that occur in the community indicate that public services are still not fully running well and obstacles are still encountered. The poor public services 
are also exacerbated by the low level of public participation and permissiveness towards illegal levies. Government's efforts to create quality, fast, easy, affordable, and measurable service quality are certainly inseparable from the problems that arise in the form of illegal levies which currently connote being the cultural roots that exist in the public service process carried out by State officials / apparatus and currently do not only occur at the ministry/instance level (central) but have developed at the local government level (Province, Regency / City) even to the smallest level (RT / RW).

The illegal levies are increasingly rampant in public services will disrupt and burden the community so that it can reduce public trust to the government, hamper economic development, can affect investment climate and decrease law authority. The high level of service uncertainty as a result of prolong and tiring service procedures are the cause of increasing number people who give up when dealing with corrupt public services. This is one of the factors instigates people to be more tolerant to illegal levies practice under implementation of public services.

On the whole, illegal levies are imposition fees or levies in a place or activity that should not have costs / additions, so that it can be interpreted as an activity to collect fees or request money forcibly by someone to another party and this is a practice of crime or criminal act. In the modus operandi, extortionists are usually followed by acts of violence, threats of violence, complicating the process, buying time, asking for compensation for those who are in a weak position or being served. That is why illegal levy tends to lead to acts of extortion and coercion which in criminal law are unlawful or criminal acts. Based on records from United Nations documents on efforts to eradicate corruption, illegal levies constitute unofficial levies, requests, receipt of all payments, gratification or other benefits, directly or indirectly, by public officials or elected representatives of a country from a private company or the public including transnational companies or individuals from other countries that are associated with the intention to do or not perform an assignment related to an international commercial transaction. Acts committed by civil servants or state administrators with the intention of benefiting themselves or others illegally are contained in the formulation of Article 12 letter e, and Article 12 letter $\mathrm{f}$ in the amendment of Law Number 31 Year 1999 to the Law Number 20 of 2001 concerning Corruption Crime.

Illegal levies as mentioned above, are also actions that lead to corrupt actions. The results of the study of various government and non-government institutions, it can be crystallized that the existence of illegal levies has been detrimental to the community. One of the effects of this rampant extortion is the high economic costs that leading to state financial losses, averaged at 20-25 trillion rupiah annually, in one sector providing public services. Can be said to be conscious or not, illegal levy has taken root in the behavior of some Indonesian people.

Another part of our society also considers these levies reasonable because they do not have much time to question matters that do not cost much. Often they also justify the levy for the sake of smooth business in place and not complicated. It is the same as allowing corruption to flourish around us and in the end the impact will return to us as a general public. It should indeed be that as citizens get public service and enjoy it in accordance with the rules that have been set, but it seems that the knowledge of the public's knowledge is used by individuals who have an interest in collecting fees that are not in accordance with the provisions.

Factors that affect the causes of extortion, include individual aspects of the perpetrator, namely the human nature of greed, lack of moral strength, inadequate income, urgent living needs, a consumptive, lazy or unwilling lifestyle and religious teachings that less applied. Meanwhile, organizational aspects, namely the lack of leadership attitudes, the absence of the right organizational culture, the absence of a true system of accountability and transparency in government agencies and the weaknesses of management control systems.

Illegal levies are acts which are referred to as extortion actions which are actually a social phenomenon that has existed in Indonesia, since Indonesia was still in the colonial period and even before that. However, the naming of acts as illegal levies (pungutan liar), was only nationally introduced in September 1977, namely when Kaskopkamtib acted as Head of Operations in Order with the Menpan to launch an Orderly Operation (OPSTIB), whose main target was extortion.

Responding to this situation the government moved quickly in eradicating illegal levies. This was proven by President Joko Widodo who signed the Presidential Decrees (Perpres) which acts as a legal umbrella for the formation of a Illegal Levies Sweeper Task Force (Saber Pungli).

The escalation of illegal levies cases that have occurred in Indonesia has damaged the joints life in the community, nation and state. One of the cases of illegal levies that revealed was in one of the Ministries after the implementation of the Limited Coordination Meeting related to legal reform, which caused a reaction from President Joko Widodo. The President warns all Ministries / Agencies to stop the practice of illegal levies (extortion). To increase the effectiveness of illegal extortion, on 20 October 2016, the President issued Presidential Decree Number 87 of 2016 concerning the Illegal Levies Sweeper Task Force (Saber Pungli) by appointing the Coordinating Minister for Politics, Law and Security (Menko Polhukam) to control and be responsible towards the activities of the Illegal Levies Sweeper Task Force (Saber Pungli) 


\section{STATEMENT OF THE PROBLEM}

From the explanation of the background above, the problem is formulated on how the Presidential Decree Number 87 of 2016 concerning the Illegal Levies Sweeper Task Force (Pungli Task Force Unit) is implemented?

\section{THEORY}

From various explanations of the theories of policies implementation above, the researcher wants to conduct research using combined factors on the theory of George C. Edward III namely factors consisting of communication, resources, disposition, bureaucratic structure, coupled with institutional character factors implementer (implementor) of the Repley theory, and added to the social, economic and political conditions of the theory of Van Matern and Van Horn.

\section{METHODOLOGY}

This study uses a qualitative approach, in an effort to answer the problems posed to answer the meaning behind reality and revealed through the collected data. The research method used is case study research with an emphasis on the case of the implementation of the Cleaning up Illegal Levies policy in East Java in the context of public policy implementation studies. This is used as an analysis related to the implementation of the Cleaning up Illegal Levies policy with institutional or institutional factors that can be a nuisance and also a driver of the successful implementation of the policy of the Cleaning up Illegal Levies in East Java. Selection of this case was motivated by the objective conditions that there was a change in the behavior of the implementer from the Cleaning up Illegal Levies policy of East Java Provincial Inspectorate as a result of the Cleaning up Illegal Levies policy. This is part of the implementation of the case studies studied.

Procedure of this study generates descriptive data in the form of written or oral words from observable behavioral people. Developed to study human life in limited cases, causal nature, but deep and comprehensive, in the sense that it does not recognize conceptual sorting of symptoms into its executive aspects, known as variables. Based on these constraints it can be understood that limitations of case studies in this study: 1. The research objectives can be human, events and documents, namely extortion suspects, witnesses, Inspectorate bureaucrats in East Java province and field implementers both police, prosecutors and others; 2 . These objectives are examined in depth as a totality in accordance with the intention to understand the various links that exist between the focus and description of the focus of the policy study on Cleaning up Illegal Levies at the Inspectorate of East Java Province.

The research conducted in two places that contradicted the character of the area, namely the office area where the leaders of the implementers and various guidelines for the clean-up policy of illegal levies originated, and the field area which consisted of executors from the police, prosecutors and Inspectorate elements to be compared. As for the informants as sources / collect data in this study are the implementors and from the community, officials at the Inspectorate of East Java Province, officers from the elements of the prosecutor's office and regional police.

To collect data needed in this study two types of techniques are used, namely: 1. Documentary study. By this technique the researcher seeks to obtain data or information by exploring and studying documents, archives and records from the claim verbal file (BAP) and the court's verdict related to the Cleaning up Policy for Illegal Levies at the Inspectorate of East Java Province; 2. Interview. By an unstructured interviewing technique, the researcher conducts question and answer and exchange ideas without an interview list; The researchers were only assisted a number of general topics about consequences of the establishment of a Cleaning up Policy at the Inspectorate of East Java Provincial which still had to be developed by the interviewer based on the answers of the informants. In its implementation, instruments are used in the form of interview guides and list of topics.

Focus description can be seen from the perspective of: 1. Capability of policy resources; 2. Capability of the policy manager; 3. Program development and improvement; 4. Increased access; 5. Improved service; 6. Administrative management; 7. Socialization and communication. Whereas institutional factors in implementation process are referred to as institutional contexts which have implications for the success or failure of the implementation Cleaning up Policy to Illegal Levies at the Inspectorate of East Java Province: 1. Policy Value Aspects; 2. Value of Efficiency on the Economics Count; 3. Synergy in the Inter-Institutional Related Operational Procedure (SOP) implementation; 4. Factors for Promoting Policy Values; 5. Policy Facilities and Infrastructure of Cleaning up Illegal Levies; 6. Implementing Organizational Structure; 7. Rule of law aspect.

This research determines the research informants as follows: 1. Head of the Inspectorate of East Java Province; 2. Police Chief of East Java; 3. Head of the East Java Provincial Prosecutor's Office; 4. People who become suspects or witnesses. However, as a variety of qualitative research literature explains that research informants in qualitative studies often develop according to the problems and dynamics of the problems learned in the field. Therefore, the research also does not close the dynamics that occur in the field.

Data analysis technique that used for the purpose of discussing results of this study used qualitative analysis techniques with a case study analysis approach both in the single case of each analyzed category and 
multiple cases for all or both of these types and categories. Whereas to guarantee the validity of data research, the researcher uses the means of validating the data research by using a good approach through triangulation process, especially triangulation of data sources and through validating their credibility and validity.

\section{DISCUSSION}

The results of the implementation of the Provincial / District / City Illegal Levies Task Force Unit activities up to 12 September 2018 are obtained as below.

For socialization / prevention gained 712 cases and for law enforcement in the form of catching operations from suspected cases there were 228 suspects and from UPP both Province, Districts and Cities as many as 133 people were hand caught operation, and obtained evidence of cash amounting to Rp. 4,862,896,300.

Meanwhile, the implementation result of illegal levies task force unit activities in Provinces, Districts and Cities in 2018, through socialization / prevention amounted to 534 cases. And law enforcement in the form of catching operations at the Provincial, District and Cities UPPs as many as 31 Capture Operations, with 39 as suspects and cash Rp. 402,280,800.

From the case development obtained P-21 data as many as 43 cases, SP3 as many as 3 cases, Sidik as many as 71 cases, overflow APIP case as many as 16 cases. The total is 133 cases. From cases classification for HandCatch Operations obtained data related to Village Fund Allocation and Village Funds of 8 Cases, Related to 15 PRONA Cases, Land Letters of 27 Cases, Licensing of 22 Cases, Extortion of 57 Cases, Retirement SK 3 Case, Aid Funds is 1 Case. Total of 133 cases.

From the results of the implementation of the extortion unit in the 2018 budget year for socialization / prevention obtained data a. UPP Province of East Java as many as 8; b. UPP Surabaya City of 153; c. UPP Situbondo of 19; d. UPP Madiun of 22; e. UPP Banyuwangi of 5; f. UPP Mojokerto of 6; g. UPP Pacitan of 5; h. UPP Probolinggo is 4; i. UPP Trenggalek of 4; j. UPP Magetan of 11; k. UPP Kediri of 2; 1. UPP Kediri City of 1; m. UPP Batu City of 10; n. UPP Blitar City of 3; o. UPP Blitar Regency is 1; p. UPP Ponorogo of 12; q. UPP Tuban of 11; r. UPP Pasuruan Regency 4; s. UPP Gresik is 1; t. UPP Bondowoso of 8; u. UPP Malang City of 2; v. UPP Kabupaten Bangkalan of 11; w. UPP Ngawi of 7; x. UPP of Lumajang of 10; y. UPP Malang of 8; z. UPP Probolinggo of 19; aa. UPP Madiun City as 4; bb. UPP Pamekasan as 11; cc. UPP Sidoarjo as 148; dd. UPP Lamongan as 1; ee. UPP Sampang Regency is 1; ff. UPP Nganjuk of 16; gg. UPP Jombang of 7. From the UPP Post data in the East Java Region, was obtained that the UPP had not reported the existence of the Coordination Post was a. UPP Sampang; b. UPP of Jember; c. UPP Kediri ; d. UPP Pasuruan.

Results of cleaning up illegal levies task force unit activities of Province/District/City up to 12 September 2018 obtained the following data. For socialization / prevention amounting to 712 cases and for law enforcement in the form of catching operations from suspected cases there were 228 suspects and from UPP both provincial, district and municipalities as many as 133 people were caught in the act of being caught red-handed, and obtaining evidence in the form of cash from operations hand catch amounting to Rp. 4,862,896,300. Meanwhile the results of the implementation of extortion eradication unit activities in the Province, District and City in 2018, through socialization / prevention amounted to 534 cases. And for law enforcement in the form of catching operations at the UPPs of Provincial, District and City are 31 Hand Capture Operations, with 39 as suspects and Rp. 402,280,800.

\subsection{Discussion of Standards and Objectives in the Implementation Provincial Government Policy of East Java on Illegal Levies Sweeper Task Force}

As it is known that the performance of policy implementation can be measured by its success rate and the size of realistic policy objectives with socio-culture at the level of policy implementers. When the size and target of the policy is too ideal (utopian), it will be difficult to realize. Van Meter and Van Horn stated that to measure the performance of policy implementation, of course, emphasizing certain standards and targets that must be achieved by policy implementers, policy performance is basically an assessment of the level of achievement of these standards and targets.

An understanding of the general intentions of a standard and policy objectives is crucial. Successful policy implementation can be frustrated when executors are not fully aware of policy standards and objectives. In terms of the standard Illegal Levies Sweeper Task Force, East Java already has it, which appears in the interview results with the implementor as follows,

"Our guideline is very clear, it is in general legislation, but the most lex specialy is specifically regulated in Presidential Decree no. 87 of 2016, which is about the formation of the cleaning up illegal levies task force, more specifically it is in the decision of the Governor of East Java Number 188/222 / kpts / 013/2018 dated 29 March 2018. Not going anywhere, that is enough. (Source, Interview with Chairperson of Executing Illegal levies Sweeper Task Force Unit, 2018). 
Policy standards and objectives have a close relationship with the disposition of implementers. The direction of the disposition of the implementers towards the standards and policy objectives is also "crucial". Implementors may fail in applying policies, because they reject or do not understand what is the purpose of a policy.

"The goal of this Illegal levies Sweeper Task Force is none other than, first, helping local governments to increase local revenue (PAD), why? because at this time there is a lot of leakage of regional income everywhere, so that the income does not enter intact to the government, for example local taxes, there are retributions, there are permits, and much more. Now the second, the target of this saber extortion is to improve the discipline of state apparatus in service to the public through transparency and standardization of services, this is in accordance with legislation and eliminating illegal levies. The third is to build and internalize the culture of anti-extortion and corruption in governance and society. (Source, Interview with Chairperson of Executing Illegal levies Sweeper Task Force Unit, 2018)"

\subsection{Discussion of Communication in the Implementation of Government Policy of East Java on Illegal Levies Sweeper Task Force Unit}

In order for public policy to be implemented effectively, according to Van Horn and Van Mater, what is the standard of goals must be understood by individuals (implementors). This is responsible for achieving policy standards and objectives, because standards and objectives must be communicated to the implementers. Communication within the framework of delivering information to policy implementers about what to become standards and objectives must be consistent and uniform (consistency and uniformity) from various sources of information.

If there is no clarity and consistency and uniformity towards a standard and policy objectives, then the standard and policy objectives are difficult to achieve. With that clarity, policy implementers can know what is expected of them and know what to do. In a public organization, for example a local government, communication is often a difficult and complex process. Process of transferring news down in the organization or from an organization to another organization, and to other communicators, often experience interference (distortion) whether intentional or not. If different communication sources provide inconsistent interpretations of a standard and purpose, or the same source of information provides interpretation that is full of conflicting, then at one point the policy implementer will find an event that is more difficult to implement a policy intensive.

Communication factor in implementing Illegal levies Sweeper policy in East Java carried out by all elements has inhibiting and supporting factors. Which can be seen below.

"The communication carried out on Illegal Levies Sweeper Task force of East Java with the Local Police is always carried out based on the invitation letter, while the obstacle is if the Chairperson is invited, but the Deputy is present, and there are also obstacles in the District or City Extortion Eradication Unit or UPP that this happens because it is related to the Budget and lack of coordination. But the problem is another factor that can support a lot. With good communication between the relevant agencies, for handling, which cases should be handled by APIP and also which cases are handled by Law Enforcement Officials, only then will all be able to proceed to further processing. (Source, interview with Inspectorate General of East Java, August 2018)".

Thus, the prospect of effective policy implementation is largely determined by communication to the implementers of policies that are accurate and consistent (Van Mater and Varn Horn, in Widodo 1974). Besides that, coordination is a powerful mechanism in policy implementation. The better the coordination of communication between the parties involved in implementing the policy, the errors will be smaller, and vice versa. In this communication factor Illegal Levies Sweeper Task Force in East Java also provides services for the community through the call center to 031-82518888, if via email addressed to saberpungli.Jawatimur @gmail.com besides that Illegal Levies Sweeper Task Force Unit of East Java also provides information services in the form of websites with addresses link address saberpungli.jatim.polri.go.id.

\subsection{Discussion on Resources in the Implementation of Policy Government of East Java on Ilegal Levies Sweeper Task Force}

The success of policy implementation depends on the ability to utilize available resources. Humans are the critical resource in determining the success of a policy implementation. Each stage of implementation requires the existence of quality human resources in accordance with the work that is implied by policies that have been determined apolitically. Regarding this resource, Illegal Levies Sweeper Task Force Unit of East Java, has it, which can be shown through the following interview.

"The resources in the form of budgets as supporters of Illegal Levies Sweeper Task Force include those in the Guideline of Illegal Levies Sweeper Task Force East Java. Which of these Illegal Levies Sweeper Task Force of East Java is supported by a budget from the Provincial Budget, it is in the form of a grant of three billion rupiah used for six Working groups, which up to September 2018 is maximally absorbed. (Source, interview with Inspectorate General of East Java, August 2018). 
"There were almost no obstacles in the area, reports from the Deputy Police Chief directly to the Regional Police Chief were then forwarded to the Central Extortion Unit (UPP). To increase the effectiveness of Illegal Levies Sweeper Task Force's performance, a centralized database is formed which functions to facilitate the Supervision and Control of UPP activities, in addition it also serves to submit reports periodically so that they are not done manually. (Source, interview with East Java Regional Police, August 2018)".

Also the following data in which human resources who are supporters of the Illegal Levies Sweeper Task Force Unit programs have the support of various existing elements, which can be seen as follows:

Responsible Agency

Chairperson

Expert Group

Secretary I

Intelligence Task Force Sub Unit

Prevention Task Force Sub Unit

Task Force Sub Unit Task Force

Justice Task Force Sub Unit

\author{
East Java Governor; \\ East Java Regional Police Irwasda; \\ East Java Governor's Expert Staff for Legal Affairs; \\ Irbidops Itwasda, East Java Regional Police; \\ Dirintelkkam East Java Regional Police; \\ Head of the Indonesian Ombudsman Representative of East Java \\ Dirreskrimsus East Java Regional Police; \\ : As Bid Pidsus East Java High Prosecutor's Office.
}

In addition to human resources, financial resources and time are significant calculations in the success of policy implementation. As stated by Derthicks (in Van Mater and Van Horn, 1974) that: "New town studies suggest that the limited supply of federal incentives were a major contributor to the failure of the program". Van Mater and Van Horn assert that policy resources are not as important as communication. These policy resources must also be available in order to facilitate the administration of the implementation of a policy. This resource consists of funds or other incentives that can facilitate the implementation (implementation) of a policy. Lack of or limited funds or other incentives in policy implementation is a major contribution to the failure of policy implementation.

The implementation of Illegal Levies Sweeper Task Force of East Java has fulfilled the requirements as stated by Van Horn Van Meter, which are data on budget resources which can be shown through the numbers in the table below:

\begin{tabular}{|c|l|c|c|c|}
\hline No. & \multicolumn{1}{|c|}{ SUB UNIT } & $\begin{array}{c}\text { BUDGET. } \\
\text { (Rp) }\end{array}$ & $\begin{array}{c}\text { ABSORBED } \\
\text { (Rp) }\end{array}$ & \% \\
\hline 1 & Expert & $109.096 .000,00$ & $12.685 .000,00$ & 11,6 \\
\hline 2 & Secretariat & $493.984 .000,00$ & $349.970 .968,00$ & 70,8 \\
\hline 3 & Prevention & $1.525 .820 .000,00$ & $195.100 .000,00$ & 12,8 \\
\hline 4 & Intelligent & $340.100 .000,00$ & $125.091 .000,00$ & 36,8 \\
\hline 5 & Prosecution & $476.000 .000,00$ & - & 0 \\
\hline 6 & Yustisi & $55.000 .000,00$ & - & 0 \\
\hline \multicolumn{2}{|r|}{ S U M } & $3.000 .000 .000,00$ & $682.846 .968,00$ & 22,76 \\
\hline
\end{tabular}

(Source, Inspectorate of East Java Province)

\subsection{Discussion on Disposition in the Implementation of Policy Government of East Java on Ilegal Levies Sweeper Task Force}

In the opinion of Van Metter and Van Horn, the attitude of acceptance or rejection of policy implementing agencies greatly influences the success or failure of public policy implementation. This is very possible because the policy implemented is not the result of the formulation of local residents who know the problems and problems they feel. But public policy is usually top down which is very likely that decision makers do not know that they cannot even touch the needs, desires or problems that must be resolved.

Their attitude is influenced by his view of a policy and how to see the influence of the policy on the interests of his organization and his personal interests. Van Mater and Van Horn (1974) explain the disposition that the implementation of policies begins screening (befiltered) first through the perceptions of the implementers within the limits of which policies are implemented. There are three types of response elements that can affect their ability and willingness to implement a policy, including the first, cognition, understanding and understanding of policy, second, the direction of their response whether accepting, neutral or refusing ( acceptance, neutrality, and rejection), and third, intensity of policy.

In the end, disposition intensity of the implementers can influence the policy performance of the implementers. The lack or limited intensity of this disposition will lead to failure of policy implementation. 
Regarding the disposition of the Illegal Levies Sweeper Task Force Unit program which is a factor rather than the obstacle and its supporters as can be shown in the interview below.

"The disposition of Illegal Levies Sweeper Task Force implementation in East Java, the inhibiting factor is the case of the descent from IRWASDA which was disposed to Crimsus (Special Crime), then from Crimsus it implemented OTT, this is another OTT, not Illegal Levies Sweeper Task Force Unit, so here is not only the Saber Pungli OTT case, but there are also other OTT cases. Now that's what makes it like this. Finally, Saber Pungli's OTT declined, right, because it was considered to be of little value. But this disposition also has supporters. The supporter is to optimize the use of personnel. There is another optimizing utilization of the work unit, and optimizing the use of infrastructure, which is located in the regional government, so that all of them can implement Illegal Levies Sweeper Task Force Unit of East Java, and can eradicate illegal levies effectively and efficiently. (Source, interview with Inspectorate General of East Java, August 2018).

\subsection{Discussion of Bureaucratic Structure in the Policy Government of East Java on Ilegal Levies Sweeper Task Force}

Discussion of the implementing agency of a policy cannot be detachable from bureaucratic structure. Bureaucratic structures are characteristics, norms, and patterns of relationships that occur repeatedly in executive bodies that have both potential and real relationships with what they have in carrying out policies. Van Horn and Van Meter show some elements that might influence an organization in implementing policies, namely 1. Competence and size of staff of a body; 2. The level of hierarchical supervision of the decisions of sub-units and processes in the implementing agency; 3. Political sources of an organization (e.g. support between legislative and executive members); 4. Vitality of an organization; 5. Level of open communication, namely a network of horizontal and vertical communication freely and a relatively high level of freedom in communication with individuals outside the organization; 6 . Formal and informal linkages of a body with a decision-making body or decision maker. If sufficient resources to implement a policy and implementers know what to do, implementation still fails if the existing bureaucratic structure blocks the coordination needed to implement the policy. Complex policies require the cooperation of many people, and waste of resources will affect the results of implementation. Changes made will certainly affect individuals and will generally affect the system in the bureaucracy. (George III Edward, implementing public policy, 1980) The policy implementation of Illegal Levies Sweeper Task Force in East Java, of course, requires a bureaucratic structure which is an instrument in implementing its policies. However can be seen below.

"Supporters from the bureaucratic structure which are united from various elements which have become a unit in the implementation of Illegal Levies Sweeper Task Force are the integration of various agencies, namely from the Prosecutor, from the Provincial Government, from Academics, from the Regional Police. But do not forget that there are also obstacles, the obstacle is the bureaucratic structure in the implementation of Illegal Levies Sweeper Task Force of East Java, which is when they are asked to be present for invitations, often invited in meetings that are often represented by representatives or others. Then, OTT the evidence is small, where is it processed? Then, the Corruption Court only exists in the provincial capital. Does this become expensive? Is that effective? Not to mention the limited budget, especially in the TUT. For example, the Bengkulu District Court Decision, which refused Pidum (Common Criminal), how was it. (Source, interview with Inspectorate of East Java Province, August 2018).

\subsection{Discussion of the Implementer Institution Character of Policy Government of East Java on Illegal Levies Sweeper Task Force}

Focus of attention on implementing agents includes formal organizations and informal organizations that will be involved in implementing the policy. This is important because the performance of policy implementation will be greatly influenced by the right characteristics and match with the implementing agents. This is related to the context of the policy to be implemented in several policies demanded by implementing a strict and disciplined policy. In other contexts, democratic and persuasive implementing agents are needed. In addition, coverage or area is an important consideration in determining policy implementing agents.

According to George Edward III, the two main characteristics of the bureaucratic structure are standard work procedures (SOP $=$ Standard Operating Procedures) and fragmentation. Standard Operating Procedures (SOP). SOPs are developed as an internal response to the limitations of time and resources from implementers and the desire for uniformity in the operation of complex and widespread organizations. Routine SOPs that are designed for typical situations in the past may inhibit changes in policy because they are not suitable for new situations or programs. SOPs are very likely to hinder the implementation of new policies that require new ways of working or new types of personnel to implement policies. The greater the policy requires changes in the routine ways of an organization, the greater the probability of SOPs hindering implementation (Edward III, 1980). 
The matters relating to the character of the implementer of Illegal Levies Sweeper Task Force of East Java can be illustrated from the explanation in the interview that follows.

"How is the readiness of the resources possessed in the Implementation of Illegal Levies Sweeper Task Force of East Java, which can be seen from the existing factors. For example, the apparatus how to prevent it and how the apparatus supported it. Our resources are capable, almost qualified, it is in accordance with the Autonomy, as in the example of the Expert Group, they are always cooperating with Academics, so that they can implement Saber Pungli, it is in accordance with what is stipulated in the Presidential Regulation. (Source, Interview with Inspectorate General of East Java, August 2018).

Fragmentation comes primarily from pressures outside the bureaucratic units, such as legislative committees, interest groups, executive officials, the State constitution and the nature of policies that affect the organization of the public bureaucracy. Fragmentation is distribution of responsibility for a policy area between several organizational units. Fragmentation is the dispersion of responsibility for a policy area among several organizational units. (George Edward III, 1980). The more actors and bodies involved in a particular policy and the more interrelated their decisions are, the less likely the success of implementation. Edward stated that in general, the more coordination needed to implement a policy, the smaller the chance to succeed (Edward III, 1980).

On the contrary, the character of the implementer of the Illegal Levies Sweeper Task Force of East Java which is hampering can be described from the explanation in the interview that is stated below. "The implementer 's character also depends on the budget, if the budget support is limited, how is that in the Regency Government, that is in the City Government, for the District and City Illegal Levies Sweeper Task Force Unit activities how, what kind of character do you want it can't, if budget support less. Then the characters also cannot be formed, if there is overlap, each other overlaps with one another, Try it is the task and personnel in the activities of the Illegal Levies Sweeper Task Force Unit and routine activities in each agency, how to assess the character of such an? This, too, is the presumption that there is an assumption that the Extortion Unit is the domain of the Police, so that other Institutions are ultimately less proactive in the activities of the Extortion Unit, how are the character of the apparatus as implementers if so? (Source, Interview with Inspectorate General of East Java, August 2018).

How can the Character of the implementing agency implementing the Illegal Levies Sweeper Task Force of East Java be interviewed as follows below. The character of the implementing agency that implements Illegal Levies Sweeper Task Force of East Java is that the implementation is in line with the trial, for example for the imposition of sanctions, so the implementation is in the Regional Police, for the disciplinary sentence from Propos, there is also a Code of Ethics (PTDH). While sanctions for the State Civil Servant of Provincial Government, for example those subject to TIPIKOR problems, the imposition of sanctions refers to Government Regulation Number 11 of 2017, which is about the Management of Civil Servants, especially those in Article 250 letter b. While those outside TIPIKOR, the imposition of sanctions refers to PP No. 53 of 2010 which is about the Discipline of Civil Servants. Already in accordance with all that in the fields, there is no problem. But the name of the obstacle still exists. Regarding the provisions or agreement for the distribution of TIPICORS or PIDUMs, there is still no right, and indeed at this time, it is still being discussed at the Central Level Extortion Saber. While the supporting factors are policies or local wisdom agreements per case between investigators and public prosecutors with court consultations. (Source, Interview with Inspectorate General of East Java, August 2018)

\subsection{Discussion of Social, Economic and Political Conditions in the Policy Government of East Java on Illegal Levies Sweeper Task Force}

The last thing that needs to be considered in order to assess the performance of policy implementation is the extent to which the external environment contributes to the success of public policy. The social, economic and political environment that is not conducive can be a source of problems from failure of policy implementation performance. Therefore, efforts to implement policies require conducive external environmental conditions. 
Regarding how the external social, economic and political conditions of the East Java community in relation to the successful implementation of Illegal Levies Sweeper Task Force can be shown as follows.

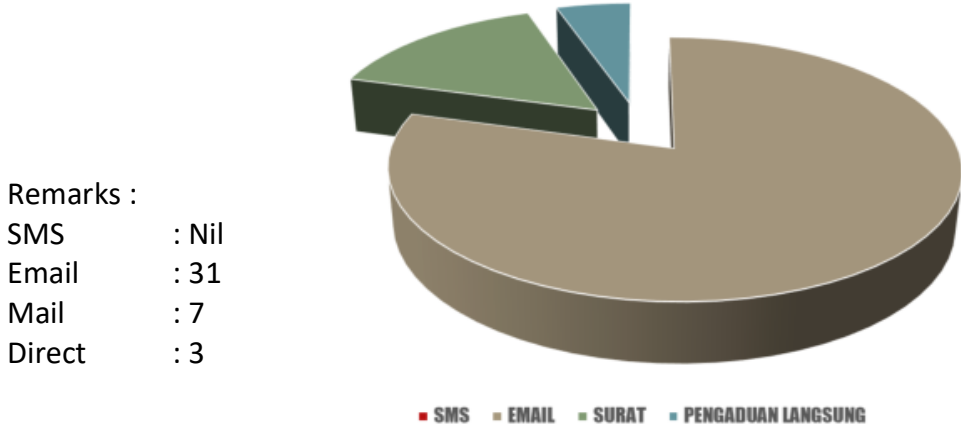

\section{CLOSING}

The results of socialization / prevention in the implementation of activities at the Provincial / District / City Illegal Levies Sweeper Task Force Unit up to September 12, 2018 were obtained in the amount of 712 cases, for law enforcement in the form of catching operations from alleged cases there were 228 suspects, and from UPP both provinces, Districts , and the City as many as 133 people were caught in the act of being caught redhanded, and the acquisition of evidence in the form of cash from the hand-catch operation amounted to Rp. $4,862,896,300$, - Results through the socialization / prevention of the implementation of illegal extortion unit activities in Provinces, Districts and Cities In 2018 there were 534 cases, for law enforcement in the form of catching operations at the Provincial, District and City UPPs as many as 31 Capture Operations, with the suspect as many as 39 people and the evidence in the form of money from the Hand Catch Operation amounted to Rp. $402,280,800$, -

In terms of Standards and Objectives of the implementation of the Illegal Levies Sweeper Task Force policy carried out by East Java Province, there are Standard and Objectives such as those in the theory of Van Meter and Van Horn. As required by the theories of Van Mater and Van Horn that in implementation there must be an understanding among individuals (implementer), where the communication factor in implementing the policy of Illegal Levies Sweeper Task Force Unit of East Java implemented by all elements has communication between organizations. Resources such as those in the theories of Van Mater and Van Horn on the implementation of the Illegal Levies Sweeper Task Force policy in East Java were found to have fulfilled the requirements, namely in the form of human resources and in the form of budgetary resources. The attitude of acceptance or rejection from the implementing agent of the Illegal Levies Sweeper Task Force policy that Van Mater and Van Horn must have if the implementation is to succeed, it turns out that in terms of the policy implementation of the Illegal Levies Sweeper Task Force East Java, the inhibiting factors are more dominant.

The policy implementation of Illegal Levies Sweeper Task Force of East Java has included a bureaucratic structure that serves as an instrument in implementing its policies. The main characteristics of the bureaucratic structure are standard work procedures (SOPs), which relate to the character of the implementers of Illegal Levies Sweeper Task Force, East Java. There was fragmentation originating mainly from pressures outside the bureaucratic units, given that Illegal Levies Sweeper Task Force was divided into many organizations / institutions. Regarding the findings of how the external social, economic and political conditions of the East Java community in relation to the successful implementation of Illegal Levies Sweeper Task Force can be assessed as conducive

From the conclusions of the results of the above research, which should be suggested as follows: 1 . The policy of Illegal Levies Sweeper Task Force Unit of East Java Province in terms of socialization / prevention and law enforcement in the form of hand-held operations to be maintained; 2. The policy of the Illegal Levies Sweeper Task Force of East Java in terms of Standards and Objectives is maintained as implementation guidelines and technical guidelines; 3. The policy of the Illegal Levies Sweeper Task Force East Java in terms of Communication must be deepened understanding among individuals (implementers) and related institutions; 4. The policy of Illegal Levies Sweeper Task Force Unit of East Java in terms of Resources in the form of human resources as well as in the form of budgetary resources is increased again; 5. The policy of Illegal Levies Sweeper Task Force Unit of East Java in terms of Disposition or acceptance and rejection of the policy Illegal Levies Sweeper Task Force on implementing agency to be better managed; 6. The Policy Illegal Levies Sweeper Task Force Unit of East in terms of Bureaucratic Structure as an instrument for implementing policies needs to be maintained; 7. The Policy of Illegal Levies Sweeper Task Force Unit of East in terms of the Character of the Implementer Institution so that it is oriented to standard work procedures (SOPs) and requires efforts to reduce fragmentation originating from pressures outside the bureaucratic units; 8. The policy of Illegal Levies Sweeper 
Task Force Unit of East in terms of social, economic and political conditions which are considered conducive to be maintained; 9. The results of this study in the future to be followed up by subsequent research so that there are new findings regarding the implementation of the Illegal Levies Sweeper Task Force program in East Java.

\section{Bibliography}

Carl J. Friedrick, 1963, Man and His Government, New York: Mc Graw Hill.

Charles O Jones, 1970, An Introduction to the Study of Public Policy, Belmont, CA: Wadswort.

Chief J.O. Udoji, 1981, The African Public Servant as a Public Policy in Africa, Addis Abeba: African Association for Public Administration and Management.

David Easton, 1953, The Political System, New York: Knopf.

Donald Van Meter, dan Carl Van Horn, 1975, "The Policy Implementation Process: A Conceptual Framework in Administration and Society". Beverly Hills: Sage Publication.

Fadillah, 2001, Prinsip-Prinsip Perumusan Kebijakan Negara. Jakarta, Sinar Grafika.

Finsterbusch, K. and A.B. Motz, 1980, Social Research for Policy Decision. Wads-worth Publishing Company

George C. Edwards III \& Ira Sharkansky, 1978, The Policy Predicament, San Fransisco: W.H. Freeman and Company.

Grindle, Merilee S, 1980, Politics and Policy Implementation in the Third World, Princeton, New Jersey, Princeton University Press.

Hogwood, Brian W, and Lewis A. Gunn, 1986, Policy Analysis for the Real World, OxfordUniversity Press.

James E. Anderson, 1979, Public Policy Making, New York: Holt, Rinehart and Winston.

Mazmanian, Daniel H., dan Paul A. Sabatier, 1983, Implementation and Public Policy, New Jersey: Scott Foresman and Company, USA.

M Irfan Islamy, 2007, Prinsip-prinsip Perumusan Kebijaksanaan Negara, Cetakan Keempat belas, Jakarta: PT. Bumi Aksara.

Mushlihin Al-Hafizh, 2012, Konsep Clean Government; Pengertian, Ketentuan, Asas.

Nicole Maldonado, 2010, The World Bank's evolving concept of good governance and its impact on human rights, Doctoral workshop on development and international organizations Stockholm, Sweden.

Nigro, A. Felix and G. Liyd Nigro, 1984, Modern Public Administration, New York: Harper International Edition.

Samudra, Wibawa, dkk, 1994, Evaluasi Kebijakan Publik, PT Raja. Grafindo Persada,Jakarta.

Riant Nugroho D, 2003, Reinventing Pembangunan, Jakarta: Gramedia Elex Media Komputendo).

CFG. Sunaryati Hartono, SH, et all, 2003, Panduan Investigasi untuk Ombudsmen Indonesia, Jakarta: Komisi Ombudsmen Nasional.

Santoso, 1992, Analisa Kebijakan Publik, PT. Tiara Wacana, Yogyakarta. Indonesia.

Siagian, P Sondang, 1994, Patologi Birokrasi: Anlisis, Identifikasi dan Terapinya. Jakarta: Ghalia 
Solichin Abdul Wahab, 2002, Analisa Kebijakan: Dari Formulasi ke Implementasi.Kebijakan Negara. Bumi Aksara. Jakarta.

Thomas R. Dye, 1953, The Political System, New York: Knopf. 1992, Understanding Public Policy. New Jersey: Englewood. Cliffs.

William N. Dunn, 2000, Analisis Kebijakan Publik, Gajah mada University Perss, 2004, Public Policy Analysis: An Introduction.2st. Ed. Upper Saddle River, NJ: Pearson Prentice Hall.

Wuryanto, Doody, 2001, Panduan Rakyat Memberantas korupsi, Bandar Lampung: Komite Anti Korupsi 